\title{
Perilaku Mencit (Mus musculus) terhadap Feses Ular Kobra Jawa (Naja sputatrix)
}

\section{The Behavior of Mice (Mus musculus) towards Feces Stimulant from Javanese Spitting Cobra (Naja sputatrix)}

\author{
KARTIKA MARTA DJAKARIA*, ANGGI NURHARDIYANTI MUNAWAROH, MARDILAH, QURAISY \\ ZAKKY, RUHAMA MAYA SARI, BERRY JULIANDI
}

Departemen Biologi, Fakultas Matemetika dan Ilmu Pengetahuan Alam, IPB University, Kampus IPB Dramaga, Bogor 16680

Diterima 19 Mei 2020/Disetujui 24 September 2020

\begin{abstract}
This research aimed to confirm the predator avoidance behavior of mice from snake droppings as a stimulant. Snake droppings are obtained from snakes fed with mice that come from the same strain as the mice being tested for response. Snake droppings were diluted into three different concentrations $(25 \%, 50 \%$, and $75 \%)$. The results showed that male individuals tend to avoid the odor stimuli than the female, it's shown by the higher avoidance duration in males than the females. The results also indicate that innate behavior takes role in the avoidance response since the mice have never been exposed to any presence of predator.
\end{abstract}

Key words: avoidance, interaction predator, prey, odor

\section{PENDAHULUAN}

Hubungan predator dan mangsa telah berevolusi selama ribuan tahun lalu. Spesies mangsa telah mengembangkan adaptasi sensorik dan perilaku untuk menghindari predator seiring berjalannya waktu. Kebanyakan spesies mangsa yang memiliki indra penciuman untuk mendeteksi bau predator adalah anggota Ordo Rodentia, salah satunya adalah Mus musculus atau mencit. M. musculus telah dijadikan sebagai hewan model percobaan semenjak awal abad ke-20 karena memiliki beberapa keunggulan, diantaranya adalah mampu beregenerasi dalam waktu singkat, kemampuan menghasilkan keturunan yang tinggi, dan memiliki variasi fenotipe (Phifer-Rixey dan Nachman 2015). Penelitian yang menggunakan hewan model mencit pada umumnya akan menggunakan $M$. musculus dengan galur yang sama. Galur merupakan sekelompok individu sejenis yang dikembangkan dari satu koloni yang sama yang saling disilangkan satu-sama lain hingga 20 generasi sehingga akan mengakibatkan penurunan heterozigositas (Phifer-Rixey dan Nachman 2015).

M. musculus memiliki indra penciuman untuk mendeteksi bau predator dan memiliki respon

*Penulis korespondensi:

E-mail: kartikadjakaria@gmail.com perilaku adaptif seperti meningkatkan kewaspadaan ataupun perilaku menghindar (Kats dan Dill 1998; Dielenberg dan McGregor 2001; Apfelbach et al. 2005; Conover 2007). Anggota Ordo Rodentia memiliki kemampuan dalam mendeteksi keberadaan predator seperti ular berdasarkan bau hewan predator tersebut. Kemampuan ini dimiliki sejak lahir (innate) dan diturunkan secara genetik (Dielenberg dan McGregor 2001).

Beberapa bau yang umum dideteksi oleh hewan mangsa sebagai tanda keberadaan predator adalah bau urin (Nolte et al. 1994) dan feses (Dickman 1992). Penelitian mengenai respon mencit terhadap feses predator telah banyak dilakukan, misalnya penelitian mengenai bau Felis silvestris tidak menimbulkan respon menghindar pada individu M. musculus (Busch dan Burroni 2015). Dickman (1992) melaporkan bahwa $M$. domesticus liar mampu menghindari jebakan yang diolesi dengan bau feses rubah Vulpes vulpes, meskipun mereka sudah saling terisolasi. M. musculus betina lebih sensitif terhadap bau feses Elaphe obsoleta (Texas Rat Snake) dibandingkan dengan indvidu-individu jantan (Weldon et al. 1987).

Feses yang dikeluarkan oleh ular berupa sisasisa metabolisme dan senyawa asam urat (uric acid) dan seringkali kedua produk sisa metabolisme ini dikeluarkan secara bersamaan melewati kloaka 
(Plummer 1991). Salah satu jenis ular yang merupakan predator alami tikus atau mencit adalah Ular Kobra Jawa (Naja sputatrix). N. sputatrix merupakan ular yang menghuni hutan dengan biotope berbatu dan belakangan ini juga sering ditemukan pada kawasan urban (Widodo et al. 2019). Persebaran utama ular ini adalah di Jawa dan Bali. N. sputarix hidup nokturnal serta diurnal, hidup terrestrial dan arboreal, dapat ditemukan pada pohon hingga $11 \mathrm{~m}$ di atas permukaan tanah (Das 2010). Ular ini adalah ular berbisa tinggi tipe neurotoksin (menyerang saraf) (Tan et al. 2017), umumnya memangsa katak, tikus, dan mamal kecil lainnya (Widodo et al. 2019).

Meskipun beragam penelitian tentang respon mencit terhadap bau predator sudah banyak dilakukan, tetapi penelitian mengenai respon $M$. musculus terhadap feses ular yang mengonsumsi M. musculus dari galur yang sama belum pernah dikaji sebelumnya. Penelitian ini dilakukan untuk menganalisis respon mencit M. musculus terhadap bau feses $N$. sputatrix. Ular diberi pakan berupa mencit dari galur yang sama dengan mencit yang diuji, untuk kemudian fesesnya dijadikan bahan untuk pengujian respon perilaku. Hipotesis penelitian ini adalah $M$. musculus yang diuji dapat menunjukkan respon menghindar karena adanya stimulus bau keberadaan predator. Penelitian ini juga menguji apakah perbedaan jenis kelamin mempengaruhi perilaku menghindar tersebut.

\section{BAHAN DAN METODE}

Waktu dan Tempat. Penelitian ini dilakukan pada Februari-Maret 2020. Pengoleksian sampel feses ular dilakukan di Ciliwung Herpetarium, Bogor. Pengujian respon mencit terhadap feses ular dilakukan di Rumah Hewan dan Laboratorium Biosistematika dan Ekologi Hewan, Departemen Biologi, Fakultas Matematika dan Ilmu Pengetahuan Alam, Institut Pertanian Bogor (IPB).

Alat dan Bahan. Bahan yang digunakan dalam penelitian berupa mencit (Mus musculus) dari galur Deutsch Democratic Yokohama (DDY) jantan dan betina berusia 10-12 minggu sebanyak 10 ekor (5 ekor pada setiap jenis kelamin). Berat badan mencit jantan dan betina yang digunakan berkisar 25-30 gram. Mencit yang digunakan berasal dari Unit Pengelola Hewan Laboratorium (UPHL), Fakultas Kedokteran Hewan, IPB. Feses Ular Kobra Jawa (Naja sputatrix) betina dewasa yang sebelumnya diberi pakan mencit dari galur yang sama sebanyak 7 ekor. Ular yang digunakan merupakan ular hasil rescue dan dikarantina di Ciliwung Herpetarium. Alat yang digunakan berupa kandang tikus, tempat uji, kamera, dan tripod. Tempat uji merupakan wadah berbahan plastik, dengan dimensi panjang $\mathrm{x}$ lebar $\mathrm{x}$ tinggi berturut-turut $45 \times 30 \times 32 \mathrm{~cm}$ (Gambar 1).

Pemeliharaan. Aklimatisasi hewan uji mencit dilakukan pada 2 box pemeliharaan yang terpisah antara kelompok jantan dan betina. Selama pemeliharaan, mencit diberikan fasilitas air minum dan diberikan pakan 2 kali sehari. Habituasi mencit terhadap tempat uji dilakukan 2 hari sebelum pengujian dengan durasi 10 menit per hari pada setiap individu mencit.

Pengoleksian Sampel Feses. Stimulan bau predator yang digunakan berasal dari Feses Ular Kobra Jawa (Naja sputatrix) betina dewasa. Feses dikoleksi setelah ular melakukan defekasi. Feses yang bercampur dengan asam urat (uric acid) dikoleksi dari kandang karantina ular. Feses diambil dengan perlahan menggunakan sarung tangan dengan cara pengambilan langsung. Proses pengambilan feses mengikuti prosedur keselamatan yang diterapkan di Ciliwung Herpetarium, yakni memakai pakaian tertutup dan pelindung wajah. Feses kemudian dipreservasi dalam lemari pendingin. Feses kemudian dilumatkan dan diencerkan kedalam tiga konsentrasi yakni $25 \%, 50 \%$, dan $75 \%$. Selama pengujian, setiap konsentasi feses diletakkan dalam cup kecil berbahan plastik di dalam balok uji.

Pengujian Respon Mencit terhadap Stimulan Feses. Pengujian dilakukan dengan metode pengamatan all occurrence sampling selama 10 menit, dengan parameter dan variabel perilaku mengacu pada Takahashi et al. (2005) yang di modifikasi, yakni Approach, Avoidance, Contact, Freezing, dan Stretched Attention. Approach merupakan perilaku mendekati stimulan yang terjadi ketika mencit berada pada radius $15 \mathrm{~cm}$ dari ujung sisi kotak uji tempat feses diletakkan. Avoidance merupakan perilaku menghindar ketika mencit berada pada radius $15 \mathrm{~cm}$ dari ujung sisi kotak yang berlawanan dengan tempat feses diletakkan. Penghitungan durasi (detik) Approach

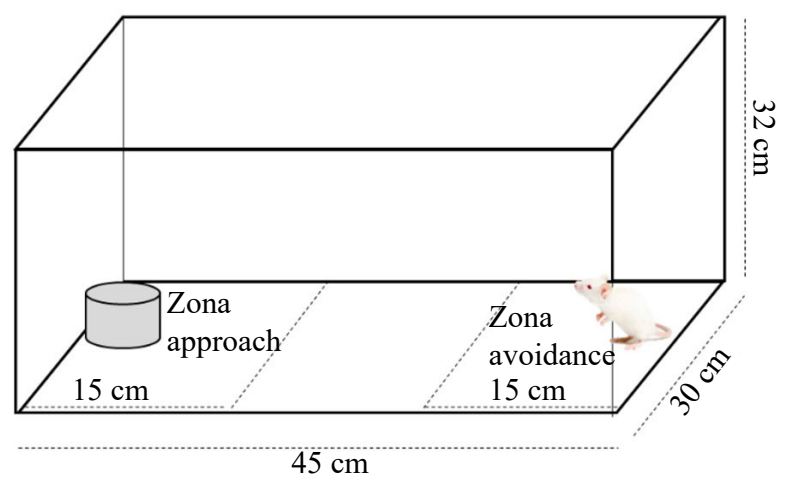

Gambar 1. Tempat uji respon mencit (Mus musculus) terhadap feses Ular Kobra Jawa (Naja sputatrix) 
dan Avoidance mulai dilakukan ketika ke empat kaki mencit berada masing-masing zona tersebut. Freezing adalah postur stasioner yang ditandai oleh berhentinya gerakan tubuh kecuali gerakan yang diperlukan untuk respirasi. Stretched attention adalah postur stasioner yang melibatkan punggung datar atau leher terentang ke arah stimulus bau. Contact merupakan perilaku ketika mencit menyentuh wadah berisi stimulus bau predator. Data yang dihitung untuk perilaku freezing, stretched attention, dan contact adalah berupa frekuensi. Pengamatan perilaku yang ditunjukkan oleh mencit direkam dengan menggunakan kamera selama 10 menit.

Analisis Data. Analisis data dilakukan dengan menghitung total durasi dan frekuensi dari masingmasing perilaku mencit pada setiap perlakuan. Analisis statistika menggunakan Analysis of Variance (ANOVA) dan Post-Hoc Analysis with Tukey's Test untuk uji pengaruh konsentrasi feses terhadap perilaku mencit, dan Two Way ANOVA untuk uji pengaruh jenis kelamin terhadap tingkah laku. Semua analisis dilakukan dengan perangkat lunak R studio.

\section{HASIL}

Pengaruh Pemberian Bau Feses Predator. Pengaruh pemberian feses mencitdengankonsentrasi yang berbeda terhadap perilaku mencit menunjukan perbedaan yang signifikan pada dua perilaku saja. Berdasarkan hasil analisis ANOVA pada mencit jantan, perilaku avoidance menunjukan perbedaan durasi yang signifikan pada setiap perbedaan konsentrasi feses yang diujikan ( $\mathrm{p}=0.030)$. Perilaku betina yang menunjukan perbedaan respon yang signifikan terhadap perbedaan konsentrasi feses adalah hanya pada frekuensi contact $(\mathrm{p}=0.049)$.

Analisis Post-hoc Tukey dilakukan untuk melihat signifikansi perbedaan respon antara dua konsentrasi feses yang berbeda. Pemberian bau feses ular dengan konsentrasi yang berbeda pada jantan berpengaruh signifikan terhadap perilaku avoidance dan contact pada jantan. Durasi avoidance menunjukan perbedaan signifikan pada konsentrasi 50\% dibandingkan kontrol $(\mathrm{p}=0.022)$. Frekuensi contact signifikan mengalami penurunan pada konsentrasi $75 \%$ dibandingkan kontrol $(p=0.043)$. Selain itu, juga terdapat perbedaan jumlah frekuensi freezing antara konsentrasi $75 \%$ dibandingkan dengan kontrol $(\mathrm{p}=0.08)$. Pada betina, perilaku yang menunjukan perbedaan yang signifikan hanya pada perilaku stretched attantion yang mengalami peningkatan pada konsentrasi $75 \%$ dibandingkan kontrol $(\mathrm{p}=0.040)$. Perilaku contact juga memperlihatkan adanya perbedaan jumlah frekuensi antara konsentrasi $75 \%$ terhadap kontrol $(\mathrm{p}=0.05)$ dan antara konsentrasi $75 \%$ dengan $25 \%$ $(\mathrm{p}=0.09)$.

Pengaruh Jenis Kelamin terhadap Respon Mencit. Hasil analisis Two-way ANOVA menunjukan bahwa tidak terdapat pengaruh yang signifikan antara perbedaan jenis kelamin terhadap perilaku mencit. Akan tetapi, mencit jantan cenderung memiliki sensitifitas terhadap bau feses predator. Hal tersebut terlihat dari durasi approach yang menurun seiring peningkatan konsentrasi (Gambar 2). Durasi avoidance pada jantan juga cenderung menurun seiring peningkatan konsentrasi. Akan tetapi tidak terlihat perubahan trend durasi approach maupun avoidance yang jelas pada betina. Frekuensi tiga perilaku lainnya menunjukan trend yang hampir sama seiring peningkatan konsentrasi feses.

Hasil pengamatan total durasi rata-rata pada zona approach dan avoidance memperlihatkan bahwa kelompok jantan menghabiskan waktu yang lebih lama pada zona approach, sedangkan betina lebih banyak berada pada zona avoidance. Akan tetapi selisih total durasi rata-rata antara zona approach dengan avoidance tidak jauh berbeda, yaitu 20 detik pada jantan dan 14 detik pada betina. Tiga perilaku yang diamati lainnya juga tidak menunjukan perbedaan total frekuensi rata-rata yang jauh berbeda antara jantan dan betina.

Perdedaan jenis kelamin tidak berpengaruh signifikan pada perilaku mencit yang diamati, sehingga kami melakukan analisis yang menggabungkan data kedua jenis kelamin tersebut (Gambar 3). Hasil analisis ANOVA pada data gabungan tersebut memperlihatkan perbedaan yang signifikan pada tiga perilaku mencit terhadap perbedaan konsentrasi feses yang diujikan. Perilaku tersebut adalah freezing $(\mathrm{p}=0.009)$, stretched attantion $(\mathrm{p}=0.025)$, dan contact $(\mathrm{p}=0.0009)$. Analisis lanjutan dengan menggunakan Post-hoc Tukey memperlihatkan bahwa pada perilakufreezing, perbedaan jumlah frekuensi yang signifikan terdapat antara konsentrasi $75 \%$ dengan kontrol $(\mathrm{p}=0.013)$ dan antara konsentrasi $75 \%$ dengan $25 \%(\mathrm{p}=0.025)$. Pada perilaku stretched attantion, perbedaan jumlah frekuensi yang signifikan terjadi antara perlakuan pada konsentrasi $75 \%$ terhadap kontrol $(\mathrm{p}=0.015)$. Perbedaan frekuensi contact yang signifikan terjadi antara pelakuan $75 \%$ dibandingakan dengan kontrol $(\mathrm{p}=0.0005)$, serta antara perlakuan $75 \%$ dengan $25 \%(\mathrm{p}=0.035)$. 

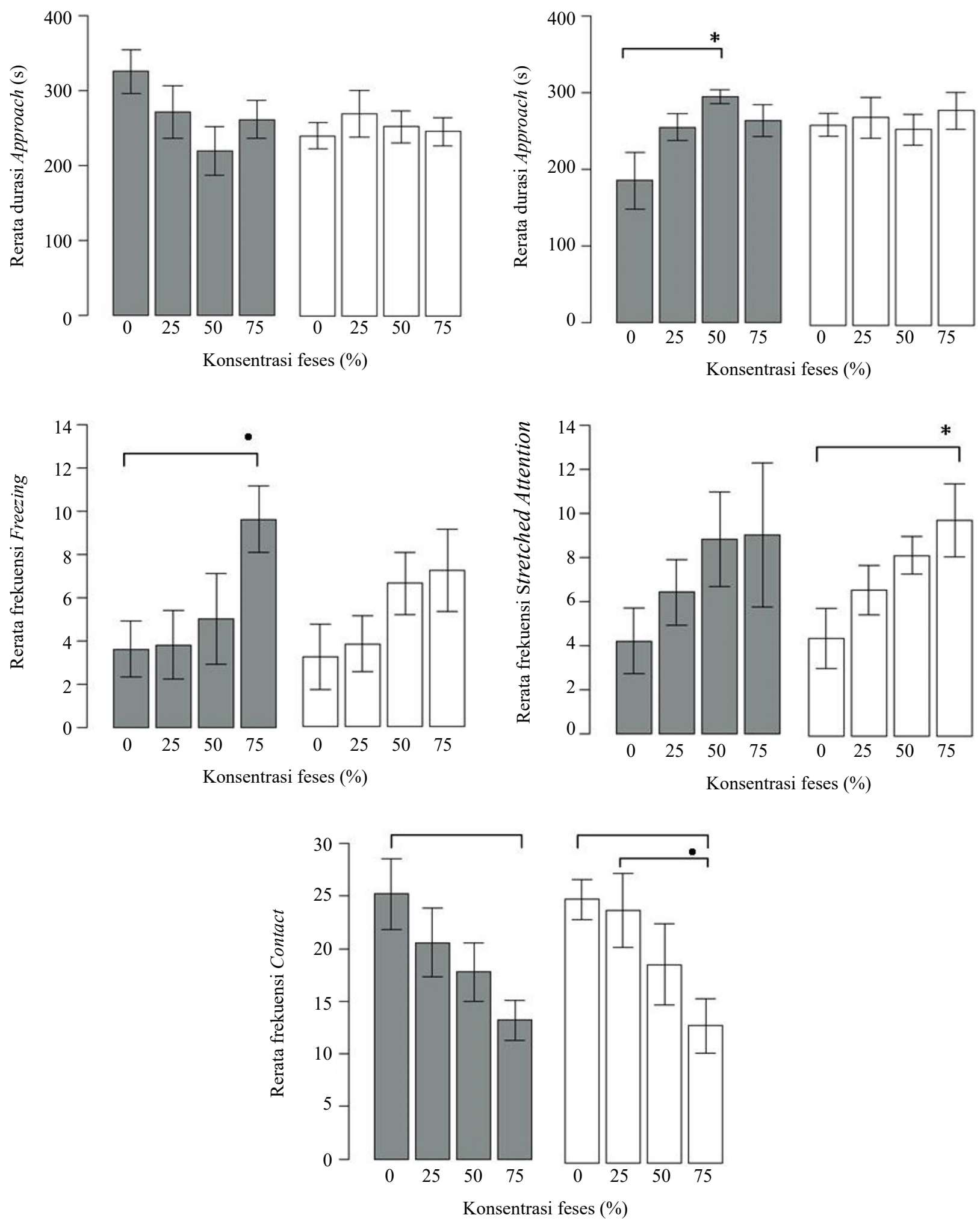

Gambar 2. Durasi dan frekuensi dari perilaku mencit (Mus musculus) jantan (hitam) dan betina (putih) terhadap aroma feses ular feses ular kobra (Naja sputatrix) dengan konsentrasi 0-75\%. Data merupakan rerata total dengan standard error. Simbol bintang menunjukan adanya perbedaan yang signifikan ( $\mathrm{p}$-value $<0.05$ ) dan simbo titik menunjukan $\mathrm{p}$-value $<0.1$ 

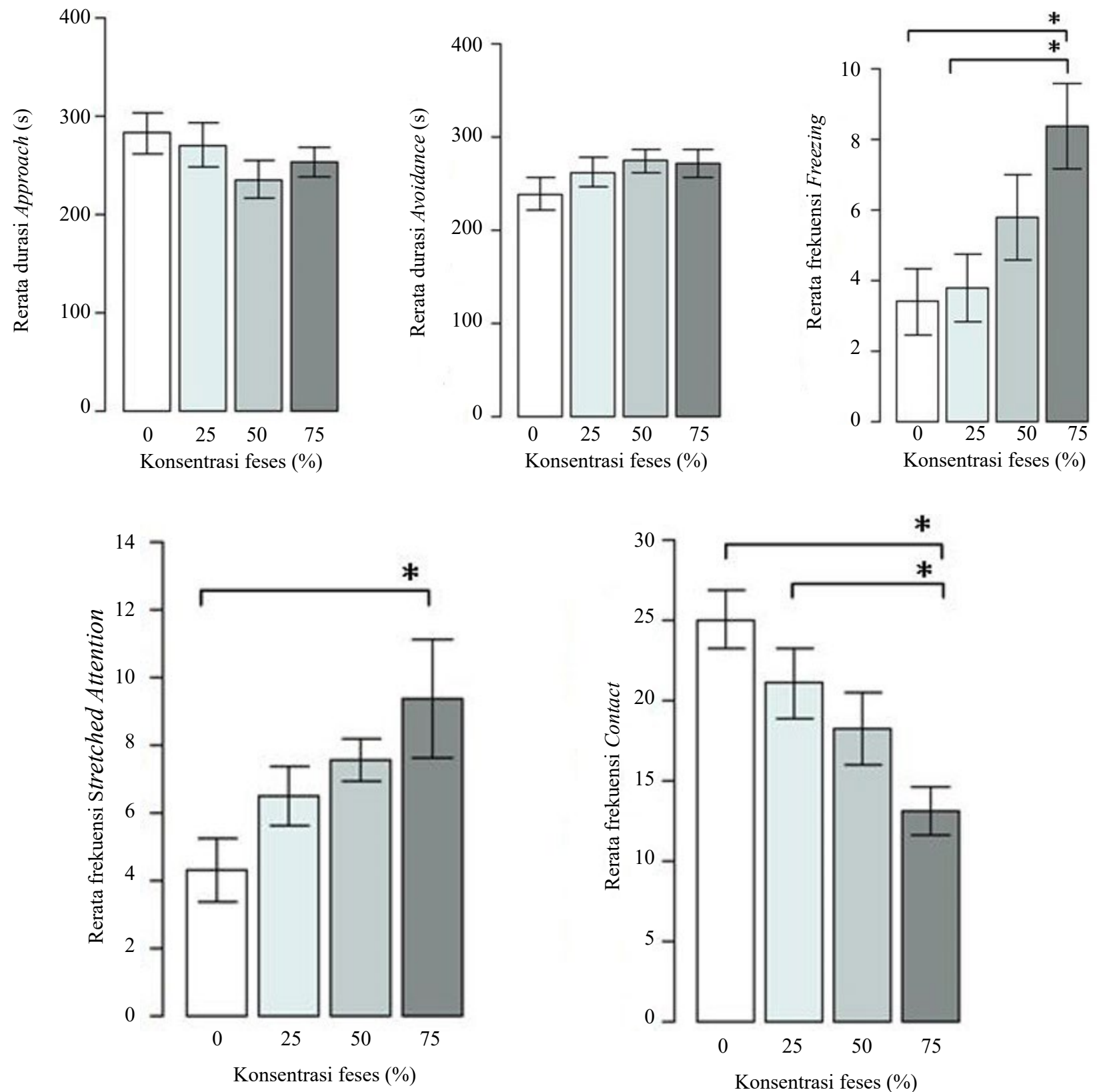

Gambar 3. Durasi dan frekuensi dari perilaku mencit (Mus musculus) gabungan jantan dan betina terhadap aroma feses ular kobra (Naja sputatrix) dengan konsentrasi 0-75\%. Data merupakan rerata total dengan standard error. Simbol bintang menunjukan adanya perbedaan yang signifikan ( $\mathrm{p}$-value $<0.05$ ) berdasarkan analisis Post-hoc Tukey

\section{PEMBAHASAN}

Hasil penelitian menunjukkan bahwa jantan lebih banyak melakukan perilaku mengeksplor benda baru dibandingkan dengan betina, yang ditunjukkan oleh lamanya durasi jantan pada zona approach apabila dibandingkan dengan betina. Hal ini disebabkan oleh adanya perbedaan perilaku mengeksplor pada jantan dan betina apabila ditempatkan secara individu maupun kelompok. Mencit jantan cenderung bergerak lebih aktif ketika ditempatkan secara individu dibandingkan saat ditempatkan berkelompok. Berbeda dengan mencit betina yang cenderung bergerak lebih aktif dan memiliki tingkat stress yang lebih rendah saat ditempatkan berkelompok dibandingkan saat ditempatkan secara individu (Palanza 2001).

Terjadinya perubahan trend perilaku yang signifikan terlihat hanya pada mencit jantan. Durasi approach terlihat memiliki korelasi negatif sedangkan durasi avoidance terlihat berkorelasi positif terhadap peningkatan konsentrasi feses. Menurunnya durasi approach dan meningkatnya durasi avoidance seiring dengan peningkatan konsentrasi feses predator yang diberikan menunjukkan bahwa mencit jantan memiliki sensitifitas lebih tinggi dibandingkan dengan mencit betina dalam merespon bau predator. Sensitifitas 
yang tinggi pada mencit jantan terhadap bau predator dapat diakibatkan oleh beberapa faktor seperti tingkat kestabilan emosi mencit jantan yang lebih baik dibandingkan dengan betina. ketika mencit jantan dan betina ditempatkan pada suatu lingkungan baru, jantan menunjukkan tingkat kecemasan yang lebih tinggi dibandingkan dengan betina (Palanza 2001). Perbedaan respon yang ditunjukkan oleh mencit jantan dan betina disebabkan oleh adanya perbedaan hormon seks yang mempengaruhi perilaku cemas pada mencit jantan dan betina (Horst et al. 2012). Pengamatan perilaku mencit betina dilakukan tanpa memperhitungkan siklus menstruasi pada mencit betina. Sama halnya dengan penelitian yang dilakukan oleh Weldon et al. (1987). Penelitian tersebut juga melaporkan bahwa mencit betina lebih sensitif terhadap bau predator dibandingkan dengan jantan. Pernyataan ini bertolak belakang dengan hasil penelitian yang menunjukkan bahwa jantan memiliki sensitifitas yang lebih tinggi terhadap bau predator dibandingkan dengan betina.

Perbedaan hasil penelitian dapat terjadi akibat adanya perbedaan fase menstruasi yang terjadi pada mencit betina saat dilakukan pengamatan. Mencit betina yang berada pada fase proestrus menunjukkan tingkat kecemasan yang lebih rendah dibandingkan mencit betina yang berada pada fase lain (Horst et al. 2012). Tingkat stress pada mencit betina kemudian akan meningkat selama periode diestrus (Romeo et al. 2003). Meningkatnya tingkat stress dan kecemasan pada betina selama periode diestrus disebabkan oleh penurunan hormon estrogen pada betina. Ketidakhadiran hormon estrogen pada betina dapat meningkatkan respon rasa takut dan cemas (Morgan dan Pfaff 2001).

Hasil uji pengaruh jenis kelamin (jantan dan betina) terhadap perilaku menunjukkan bahwa tidak ada pengaruh signifikan pada perilaku mencit yang diamati secara statistik, yang berarti perilaku antara mencit jantan dan betina ketika dihadapkan dengan feses predator menunjukkan perilaku yang sama (Gambar 2). Akan tetapi, ketika data perilaku jantan dan betina digabungkan, hasil analisis menunjukkan adanya perbedaan yang signifikan pada beberapa perilaku mencit terhadap perbedaan konsentrasi feses yang diujikan (freezing, stretched attention, dan contact) (Gambar 3).

Tinggi rendahnya konsentrasi feses predator yang diberikan secara bertahap mampu menimbulkan respon yang berbeda pada mencit. Hasil penelitian yang telah dilakukan menunjukkan respon ketakutan meningkat seiring peningatan konsentrasi feses predator. Pernyataan ini didukung oleh data hasil penelitian yang menunjukkan trend perilaku approach dan contact yang menurun, dan perilaku avoidance, freezing, dan stretched attention yang meningkat pada mencit jantan seiring meningkatnya konsentrasi feses yan diberikan. Dalam penelitian ini juga memperlihatkan bahwa mencit menunjukkan respon stress yang lebih rendah apabila ditempatkan bersama feses predator dengan konsentrasi yang lebih rendah. Menurut Hacquemand et al. (2013) konsentrasi rendah dari feses predator hanya akan menginduksi respons kecemasan sementara, sedangkan konsentrasi tinggi mampu menginduksi respon kecemasan dan ketakutan. Rasa takut umumnya diatur oleh inti pusat amigdala dan rasa cemas berasal dari nukleus inti stria terminalis (BNST). Namun, rangkaian neurobiologis terkait dengan respon takut dan cemas masih banyak diperdebatkan. Beberapa penelitian menunjukkan bahwa kecemasan dan ketakutan menyangkut fisiologi dan perilaku secara luas namun, sebagian penelitian menunjukkan bahwa respon ini sangat bergantung pada neurocircuitries yang berbeda.

Takahashi et al. (2005) mengkategorikan respon stretched attention sebagai respon takut yang dihasilkan oleh mencit terhadap feses predator dalam ethogram. Sejalan dengan penelitian yang dilakukan oleh Takahashi et al. (2005), penelitian yang telah dilakukan menunjukkan trend kemunculan perilaku stretched attention yang semakin meningkat seiring dengan peningkatan konsentrasi feses ular yang diberikan, baik pada mencit jantan maupun mencit betina. Respon rasa takut dan cemas yang dialami oleh mencit berasal dari adanya bau predator yang diberikan secara bertahap. Umumnya mencit dapat menerima bau melalui dua organ sensorik yaitu sistem penciuman utama dengan epitel penciuman yang terletak di hidung dan organ veromonasal (VNO) yang terletak antara mulut dan hidung. Mencit merupakan hewan yang aktif pada malam hari sehingga indera penciuman dan perasa merupakan kemampuan utama pada mencit untuk mendeteksi keberadaan predator (Eisenberg 1981).

Meningkatnya perilaku freezing yang ditunjukkan berbanding terbalik dengan perilaku contact yang semakin menurun seiring penambahan konsentrasi feses baik pada mencit jantan maupun mencit betina. Tingginya konsentrasi feses yang diberikan berbanding lurus dengan bau feses yang dihasilkan, sehingga menimbulkan respon berbeda pada perilaku contact dan freezing yang ditunjukkan oleh mencit. Hal ini disebabkan oleh adanya pengaruh bau feses terhadap sistem saraf yang berpotensi mempengaruhi perilaku melalui tindakan pada sistem endokrin yang selanjutnya mengubah aktivitas sistem saraf pusat. Ada sejumlah penelitian yang menyelidiki efek paparan predator pada sistem endokrin serta beberapa 
penelitian tentang efek dari bau predator salah satunya dilakukan oleh Figueiredo et al. (2003).

Tidak dipungkiri bahwa perilaku innate berperan dalam penelitian ini. Mencit M. musculus yang tidak mengenal alam liar karena tumbuh dan berkembang dibawah standar laboratorium, akan tetap menunjukkan respon menghindar ketika dihadapkan dengan feses dari predator alaminya. Hal ini mengindikasikan bahwa perilaku innate pada mencit berperan dalam penelitian ini. Perilaku innate menghindari dan peningkatan kewaspadaan terhadap predator ditunjukkan dengan meningkatnya perilaku avoidance, freezing, dan stretched attention pada mencit seiring dengan bertambahnya konsentrasi feses predator yang diberikan. Perilaku menghindar mencit merepresentasikan sebagai respon mangsa yang mengalami rasa takut dan cemas ketika ditempatkan bersamaan dengan feses predator alaminya.

\section{UCAPAN TERIMA KASIH}

Terimakasih kepada Ciliwung Herpetarium atas kerjasama dalam pengadaan fasilitas dan feses ular. Kami juga mengucapkan terimakasih kepada Dr. Ir. Rika Raffiudin, M.Si atas arahan dan masukan yang diberikan untuk penelitian ini.

\section{DAFTAR PUSTAKA}

Apfelbach R, Blanchard CD, Blanchard RJ, Hayes RA, McGregor IS. 2005. The effects of predator odors in mammalian prey species: a review of field and laboratory studies. Neurosci Biobehav Rev 29:1123-1144.

Busch M, Burroni NE. 2015. Foraging activity of commensal Mus Musculus in semi-captivity conditions. Effect of predator odours, previous experience and moonlight. Pest Management Science 71:1599-1604.

Conover MR. 2007. Predator-Prey Dynamics: The Role of Olfaction. Boca Raton:CRC Press.

Das I. 2010. A Field Guide to The Reptiles of South-East Asia. 1 ed. London:New Holland Publishers.

Dickman CR. 1992. Predation and habitat shift in the house mouse, Mus domesticus. Ecology 73:313-22.

Dielenberg RA, McGregor IS. 2001. Defensive behavior in rats toward predatory odors: a review. Neurosci Biobehav Rev 25:597-609.
Eisenberg JF. 1981. The Mammalian Radiations. Chicago. The University of Chicago Press.

Figueiredo HF, Bruestle A, Bodie B, Dolgas CM, Herman JP. 2003. The medial prefrontal cortex differentially regulates stress-induced c-fos expression in the forebrain depending on type of stressor. Eur J Neurosci 18:2357-2364.

Hacquemand R, Choffat N, Jacquot L, Brand G. 2013. Comparison between low doses of TMT and cat odor exposure in anxiety-and fear-related behaviors in mice. Behavioural Brain Research 238:227-231.

Horst JP, Kloet ER, Scha "chinger H, Oitzl MS. 2012. Relevance of stress and female sex hormones for emotion and cognition. Cell Mol Neurobiol 32:725-735.

Kats LB, Dill LM. 1998. The scent of death: chemosensory assessment of predation risk by animals. Ecoscience 5:361-394.

Morgan MA, Pfaff DW. 2001. Effects of estrogen on activity and fear-related behaviors in mice. Hormones and Behavior 40:472-482.

Nolte DL, Mason JR, Epple G, Aronov E, Campbell DL. 1994. Why are predator urines aversive to prey. J Chem Ecol 20:1505-16.

Palanza P. 2001. Animals model of anxiety and depression: how are females different?. Neuroscience and Behavioral Reviews 25:219-233.

Phifer-Rixey M, Nachman MW. 2015. Insights into mammalian biology from the wild house mouse Mus musculus. The natural history of model organism 4:1-13.

Plummer MV. 1991. Patterns of feces production in free-living green snakes, Opheodrys aestivus. Journal of Herpetology 25:222-226.

Romeo DR, Mueller A, Sisti HM, Ogawa S, McEwen BS, Brake WG. 2003. Anxiety and fear behaviors in adult male and female C57BL/6 mice are modulated by maternal separation. Hormones and Behavior 43:561-567.

Takahashi, Lorey K., Brandy R. Nakashima, Hyechong H, Kendra W. 2005. The smell of danger: a behavioral and neural analysis of predator odor-induced fear. Neuroscience and Biobehavioral Reviews 29:1157-1167.

Tan NH, Wong KY, Tan CH. 2017. Venomics of Naja sputatrix, the javan spitting cobra: a short neurotoxin-driven venom needing improved antivenom neutralization. Journal of Proteomics 157:18-32.

Weldon PJ, Frances MD, George AM. 1987. Responses to snake odors by laboratory mice. Behavioural Processes 14:137-146.

Widodo S, Kholies N, Lestari F, Abinawanto, Bowolaksono A. 2019. Snake diversity at Universitas Indonesia's Urban Forest. 9th Annual Basic Science International Conference 2019. 